\title{
Study of body fluid samples using flow cytometry: Six years of experience at the Hospital Universitario San Ignacio - Pontificia Universidad Javeriana, Bogota - Colombia
}

\author{
Alba Campos ${ }^{1}$, Laura Trujillo ${ }^{2}$, Derly López ${ }^{2}$, Lina Beltrán ${ }^{2}$, Eliana Arias ${ }^{1}$, Graciela Vélez$^{1}$, \\ Antonia Infante ${ }^{1}$, Iliana De Los Reyes ${ }^{3,7}$, Martha Vizcaíno ${ }^{3,7}$, Paula Carolina Guzmán ${ }^{3,7}$, \\ Maria Victoria Herrera ${ }^{3}$, Julio Solano ${ }^{3}$, Dario Londoño $0^{4}$, Alejandra Cañas ${ }^{4}$, Felipe Pretelt ${ }^{5}$, \\ Juan Carlos Pérez ${ }^{6}$, Claudia Cardozo ${ }^{1}$, Susana Fiorentino ${ }^{8}$, Sandra Quijano ${ }^{1,8, *}$
}

\author{
Edited by \\ Juan Carlos Salcedo-Reyes \\ (salcedo.juan@javeriana.edu.co) \\ 1. Área de Citometría de Flujo \\ Laboratorio Clínico, Hospital \\ Universitario San Ignacio, Bogotá, \\ Colombia. \\ 2. Carrera de Bacteriología, Facultad \\ de Ciencias Pontificia Universidad \\ Javeriana, Bogotá, Colombia. \\ 3. Unidad de Hematología y Oncología, \\ Hospital Universitario San Ignacio, \\ Pontificia Universidad Javeriana, \\ Bogotá, Colombia. \\ 4. Unidad de Neumología Hospital \\ Universitario San Ignacio, Pontificia \\ Universidad Javeriana, Bogotá, \\ Colombia. \\ 5. Unidad de Neurología Clínica \\ Hospital Universitario San Ignacio, \\ Bogotá, Colombia. \\ 6. Unidad de Neuropediatría Hospital \\ Universitario San Ignacio, Bogotá, \\ Colombia. \\ 7. Departamento de Pediatría, Facultad \\ de Medicina Pontificia Universidad \\ Javeriana, Bogotá, Colombia. \\ 8. Grupo de Inmunobiología y \\ Biología Celular Departamento de \\ Microbiología, Facultad de Ciencias \\ Pontificia Universidad Javeriana, \\ Bogotá, Colombia. \\ *squijano@javeriana.edu.co
}

OPEN - ACCESS

\begin{abstract}
Flow cytometry (FCM) was implemented in 2008 at the Pontificia Universidad Javeriana and later at the Hospital Universitario San Ignacio to examine special samples of patients with hematological malignancies and solid tumors other than bone marrow and peripheral blood for diagnosis and monitoring. This study describes the main findings of special sample evaluation over a six-year period. In all, 1070 samples of body fluids from patients with benign and malignant diseases were examined by FCM. These samples were stabilized with TransFix ${ }^{\mathrm{TM}}$ and stained with six-color immunophenotyping panels. Samples included cerebrospinal fluid, bronchoalveolar lavage, pleural fluid, pericardial fluid and ascite fluid from patients with acute and chronic leukemia, myelodysplastic syndromes, lymphomas, myeloma, autoimmune diseases, immunodeficiencies and solid tumors, among others. Flow cytometry provided important information for the classification and detection of minimal numbers of tumor cells in leukemia and lymphoma cases. This work represents the first national report describing FCM implementation in special samples for diagnosis and clinical monitoring of patients with malignant and benign pathologies.
\end{abstract}

Keywords: body fluids; flow cytometry; immunophenotype.

\section{Introduction}

At present Flow Cytometry (FCM) represents a diagnostic tool with high sensitivity and specificity. It is an indispensable tool recommended for routine clinical diagnosis, immunological classification, and post-treatment follow-up of patients with various types of diseases, including hematological malignancies, solid tumors, infectious diseases, and immune deficiency [1-3]. Analysis by FCM can be performed on different types of biological samples, such as bone marrow (BM), peripheral blood (PB), stem cell grafts, umbilical cord tissue biopsies, and body fluids, among others [1]. Body fluid samples require special attention due to cell viability diversity, limited sample volume 
Received: 29-11-2016

Accepted: 20-05-2017

Published on line: 10-06-2017

Citation: Campos A, Trujillo L, López D, Beltrán L, Arias E, Vélez G, Infante A, et al. Study of body fluid samples using flow cytometry: Six years of experience at the Hospital Universitario San Ignacio - Pontificia Universidad Javeriana, Bogota - Colombia, Universitas Scientiarum,

22(2): 123 - 143, 2017.

doi: 10.11144/Javeriana.SC22-2.sobf

Funding: The authors appreciate the financial support provided by the Pontificia Universidad Javeriana and Hospital Universitario San Ignacio.

Electronic supplementary material: $\mathrm{N} / \mathrm{A}$ and content variability, including cell concentration [4 - 5]. Furthermore, within less than six hours after their collection, these samples demonstrate decreased cell viability and diminished quality, presenting challenges for FCM analysis [4 - 7].

Consequently, over the last decade, use of commercially available cell stabilization solutions has been recommended. These solutions can preserve PB and cerebrospinal fluid (CSF) samples over time periods greater than one week after collection [4, 8 - 9]. This stabilization preserves cellularity and integrity of both cell surface and intracellular antigens [9].

The Pontificia Universidad Javeriana flow cytometry service at the School of Sciences was established in 2008 to implement FCM in the study of stabilized body fluids. Since then at the time of collection samples are fixed with Transfix ${ }^{\mathrm{TM}}$ (Cytomark, Buckingham, UK) [2, 4 - 5]. This service was then transferred to the Hospital Universitario San Ignacio, where FCM is currently performed. Today, special samples, such as cerebrospinal samples from pediatric and adult patients with various diseases that require correct classification and/or staging are evaluated. In our experience FCM has significantly contributed to the detection of tumor populations that have infiltrated various tissues such as the central nervous system, which is a clinical complication associated with increased aggressiveness and poor prognosis in patients with acute leukemia and lymphoma $[2,4-5,7,10]$. Compared with morphological studies FCM detects with greater sensitivity, identifying even very low tumor cell populations numbers $(<0.01 \%)$. This is an advantage over morphological techniques, which cannot detect low numbers of malignant cells due to lower sensitivity. Moreover, tumor cells may be detected by FCM before onset of clinical symptoms [4, 10 - 12].

Currently in Colombia, no results have been published related to FCM implementation for stabilized body fluids study. In the presentwork, we report the main findings of FCM body fluid evaluation over a period of six years at the Pontificia Universidad Javeriana and Hospital Universitario San Ignacio. These include technical recommendations for sample processing and analysis in the pre-analytical and analytical phases, absolute and relative cell counts of normal and tumor cell populations, sample volumes, types of diseases, in addition to clinical time point evaluation.

Implementation of our experience will be useful in our country for diagnosis in other cytometry services, as a fundamental tool in clinical practice.

\section{Materials and Methods}

We describe special fluid samples $(n=1070)$ processed and analyzed from June 2008 to June 2014 at Pontificia Universidad Javeriana and Hospital Universitario San Ignacio. Collected information included sex, age, and diagnosis, type of sample, volume, cellularity, tumor infiltration rate, and study justification (diagnosis, monitoring, relapse or progression).

Only body fluids samples that were fixed with Transfix ${ }^{\text {TM }}$ (Cytomark, Buckingham, UK) were included in the study.

Results were analyzed with non-parametric statistics. Median, mean \pm SD and value range were calculated using the SPSS software program (SPSS 19, Chicago, IL, USA). 
Statistical significance was determined by Wilcoxon or Mann-Whitney $U$ tests. P-values of $\mathrm{p}<0.05^{*}$ and $\mathrm{p}<0.01^{* *}$ were considered statistically significant.

All individuals gave their written informed consent for obtaining the special samples and the study was approved by the Ethics Committe of the Hospital Universitario San Ignacio, Bogotá, Colombia.

Protocol used for processing, labeling, acquisition and analysis of special samples (body fluids) by FCM

The Colombian Consensus of FCM was established in 2008 [6]. It recommended body fluids samples (specifically CSF) be stabilized from the time of collection in tubes with Transfix ${ }^{\text {TM }}$ (Cytomark, Buckingham, UK), a commercially available fixative agent (Barnett D. Patent WO 95/01796, 1995). This method has been validated in previous studies $[2,4-5,13]$. Transfix ${ }^{\mathrm{TM}}$ is a cellular stabilization reagent containing a buffer with an aliphatic aldehyde (AA) that fixes cells by cross-linking amino-acid residues. In addition, it contains heavy metal salts, which reduce excessive autofluorescence caused by AA. Hence, this fixative preserves samples for longer periods (up to 10 d) $[4,13]$. In the pre-analytical phase, Transfix ${ }^{\text {TM }}$ was immediately added to the samples at the time of collection by the attending clinician. Once stabilized, samples were transported to the laboratory at $4{ }^{\circ} \mathrm{C}$. It is recommended that specimens be incubated with Transfix ${ }^{\mathrm{TM}}$ for at least $18 \mathrm{~h}$ prior to processing, because this leads to higher leukocyte counts and improves tumor cell detection [13]. The detailed sample processing is shown in Figure 1.

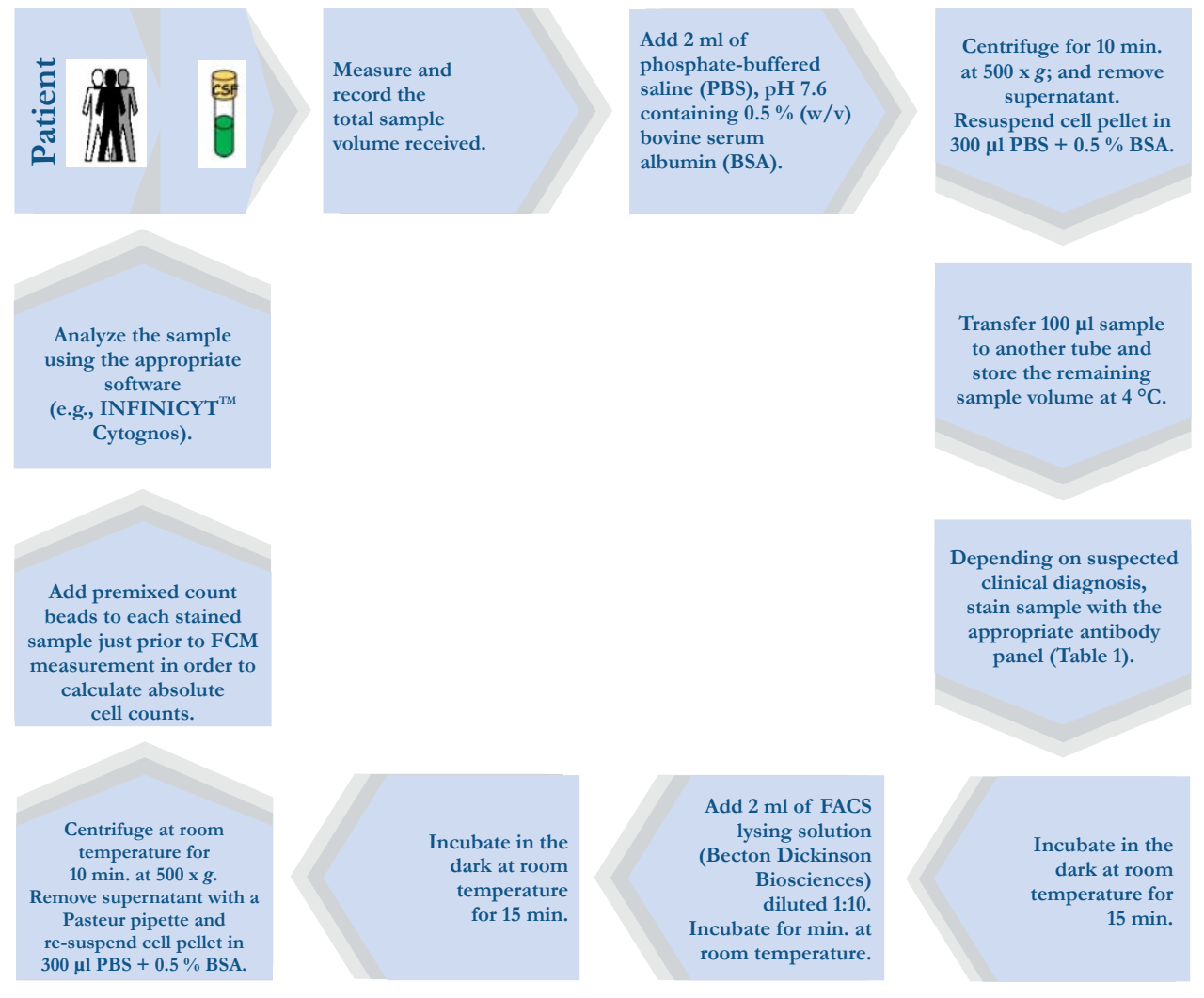

Fig. 1. Detailed sample processing. 
To calculate the absolute number of each cell subpopulation, apply the following equation $[4-5,14]$ :

$$
\frac{\text { Cells }}{\mu \mathrm{L}}=\frac{\text { events in cell subset gate }}{\text { events in beads gate }} \times \frac{\text { beads added per tube }}{\text { volume of sample }(\mu \mathrm{L})} \times \text { Correction factor }
$$

where, the total number of beads added to the tube is calculated as the volume of beads added to the tube (e.g., $20 \mu \mathrm{L}$ ) multiplied by the beads concentration (beads $/ \mu \mathrm{L}$ ) (data are provided by the manufacturer). The volume of the sample is the total volume at the time of collection. The correction factor is assumed as equal to the initial volume of the sample (e.g., $5000 \mu \mathrm{L}$ ) divided by the volume of the concentrated sample used for staining in each tube (e.g., $100 \mu \mathrm{L}$ ) in such a way that, in the protocol described, the correction factor is: $5000 \mu \mathrm{L} / 100 \mu \mathrm{L}=50$.

Analysis:

1. For the analysis, classify clusters of more than 25 events fulfilling the above criteria as positive, clusters of 10 events to 25 events as suspicious, and clusters of fewer than 10 events as negative [5].

2. If after the analysis no tumor infiltration is detected, the process should be repeated with the remaining sample volume $(200 \mu \mathrm{L})$, with the same combination of antibodies in order to increase assay sensitivity. Conversely, if tumor infiltration is detected, and depending on the total number of cells $/ \mu \mathrm{L}$, perform an additional panel to characterize the cell population immunophenotype.

3. Generate the analysis report.

For simultaneous staining of membrane and intracellular antigens, a fixation and permeabilization kit (IntraStain-Dako) was used. First, the membrane antigens (step 7) were stained, and then the sample was incubated with $100 \mu \mathrm{L}$ of fixative solution (Reagent A). Next, $100 \mu \mathrm{L}$ of permeabilization solution (Reagent B) was added to the antibodies against the intracellular antigens. Last, incubation was performed for $30 \mathrm{~min}$ at room temperature in the dark, followed by washes with PBS $+0.5 \%$ albumin (step 10 onwards).

\section{Results}

Between June 2008 to June 2014 at the Pontificia Universidad Javeriana and Hospital Universitario San Ignacio FCM core facility, 1070 special samples from 653 males $(61 \%)$ and 417 females (39\%) were studied retrospectively The mean age of the patients at the time of analysis was 37 years (range: 3 months old to 88 years).

The majority of the samples consisted of CSF ( $\mathrm{n}=932 ; 87.1 \%$ of cases), followed by while pleural fluid samples ( $\mathrm{n}=95 ; 8.9 \%$ ). Broncho alveolar lavage ( $\mathrm{n}=24 ; 2.2 \%)$, pericardial fluid $(\mathrm{n}=8 ; 0.7 \%)$, peritoneal fluid $(\mathrm{n}=7,0.7 \%)$, ascites $(\mathrm{n}=3,0.3 \%)$, and synovial fluid $(\mathrm{n}=1 ; 0.1 \%)$ represented fewer samples (Figure 2). Sample volumes were variable and ranged from $0.2 \mathrm{~mL}$ (in CSF samples) to $60 \mathrm{~mL}$ (in samples of pleural fluid) (Figure 3). All samples were stabilized with TransFix ${ }^{\mathrm{TM}}$ (Cytomark, Buckingham, UK) at the time of collection. 


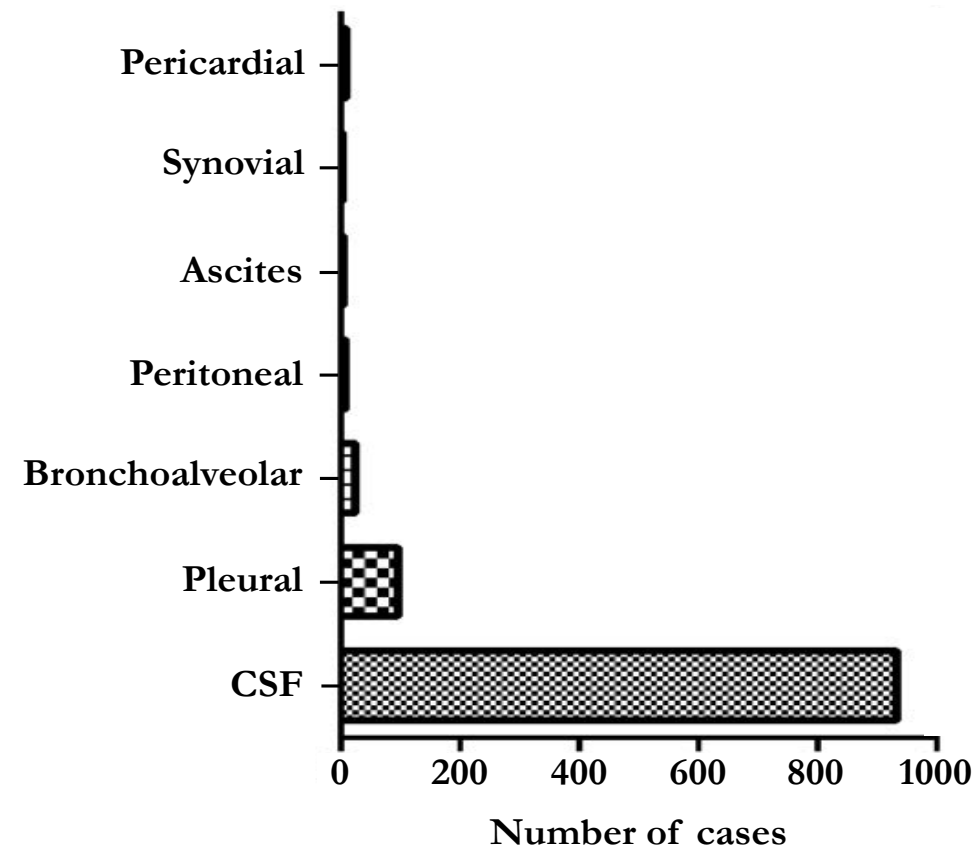

Fig. 2. Distribution of cases according to sample collected and analyzed by flow cytometry. CSF: cerebrospinal fluid.

According to clinical diagnosis most cases were acute leukemia $(\mathrm{n}=606$ : B cell acute lymphoblastic leukemia, 495; T cell acute lymphoblastic leukemia, 59, acute myeloblastic leukemia, 23; biphenotypic acute leukemia, 6; and biclonal acute

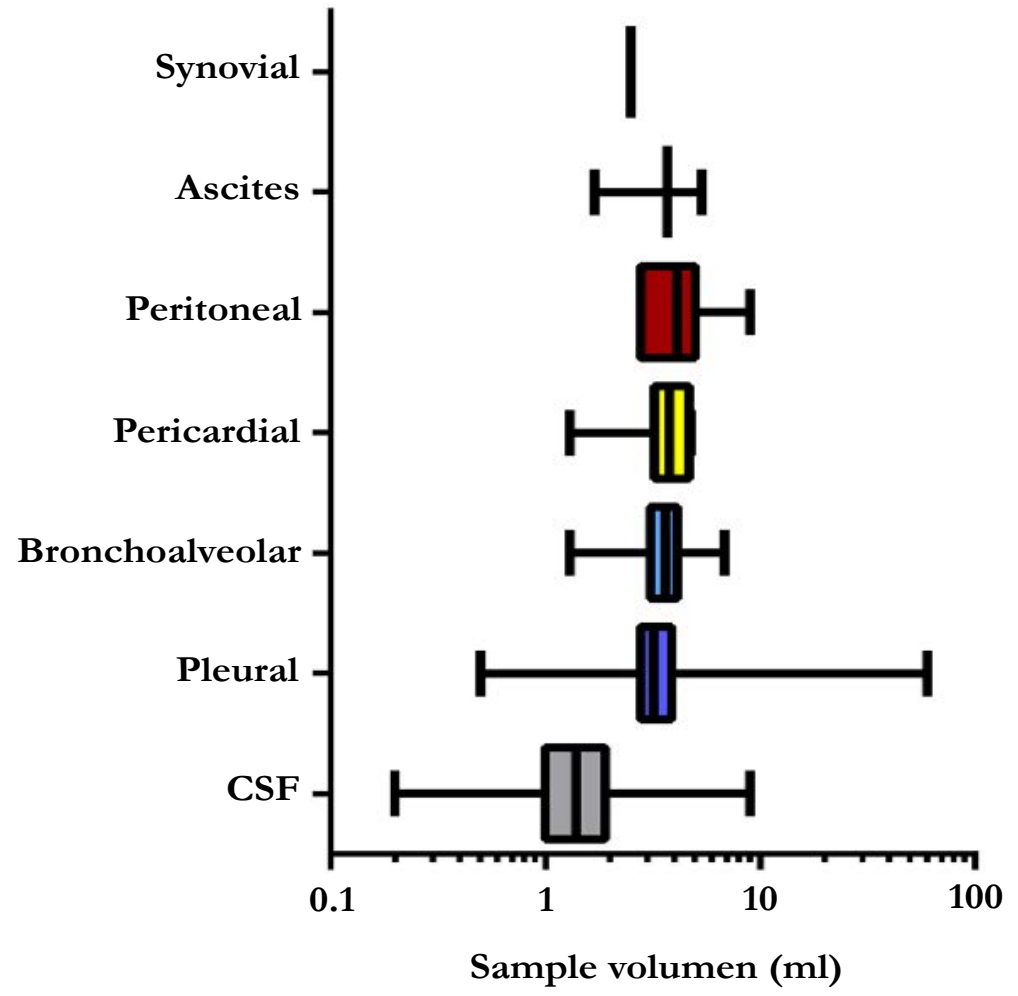

Fig. 3. Body fluid sample volumes (Mean $\pm \mathrm{SD}$ for each special sample). Volumes are in $\mathrm{ml}$. CSF: cerebrospinal fluid. 
leukemia, 3). Other cases were Non-Hodgkin Lymphomas (NHL) ( $\mathrm{n}=317$ : B-NHL, 282; and T-NHL, 35), Hodgkin lymphoma (HL) $(n=8)$, chronic myeloid leukemia $(\mathrm{CML})(\mathrm{n}=12)$, myelodysplastic syndrome (MDS) $(\mathrm{n}=5)$, multiple myeloma $(\mathrm{MM})$ $(\mathrm{n}=5)$, and solid tumors $(\mathrm{ST})(\mathrm{n}=21)$. The remaining samples $(\mathrm{n}=96)$ included patients with neurological symptoms, patients infected with human immunodeficiency virus $(\mathrm{HIV}+)$, and patients with autoimmune diseases, infections, and migraine, among other conditions (Figure 4). In all, 347 cases were analyzed at diagnosis (32\%), 682 were analyzed during clinical follow-up $(64 \%)$ and 41 were analyzed at relapse (4\%).

Analysis of cerebrospinal fluid (CSF) samples

The total number of CSF samples analyzed was 932. The pathological condition most often identified was infiltration by B cell acute lymphoblastic leukemia (B-ALL) (54\% of cases), followed by B-NHL (26\%) (Figure 5A). Among the "other" category, of the total CSF samples, representing 6\% (63 samples) included cases diagnosed with meningoencephalitis, autoimmune diseases, infectious diseases or solid tumors.

Of all the samples tested, $19 \%$ demonstrated tumor infiltration; while the remaining $81 \%$ were tumor cell-free (Figure 5B). In patients with positive tumor infiltration, the CSF samples showed a higher absolute number of total cells/ $\mu \mathrm{L}$ including $\mathrm{T}$ lymphocytes, monocytes and neutrophils compared with CSF samples that were negative for tumor infiltration (Table 1). Notably, FCM was able to detect a minimum number of tumor cells $/ \mu \mathrm{l}$ (from $0.01 / \mu \mathrm{L}$ ). Representative CSF analyses are shown in Figures 6 - 8.

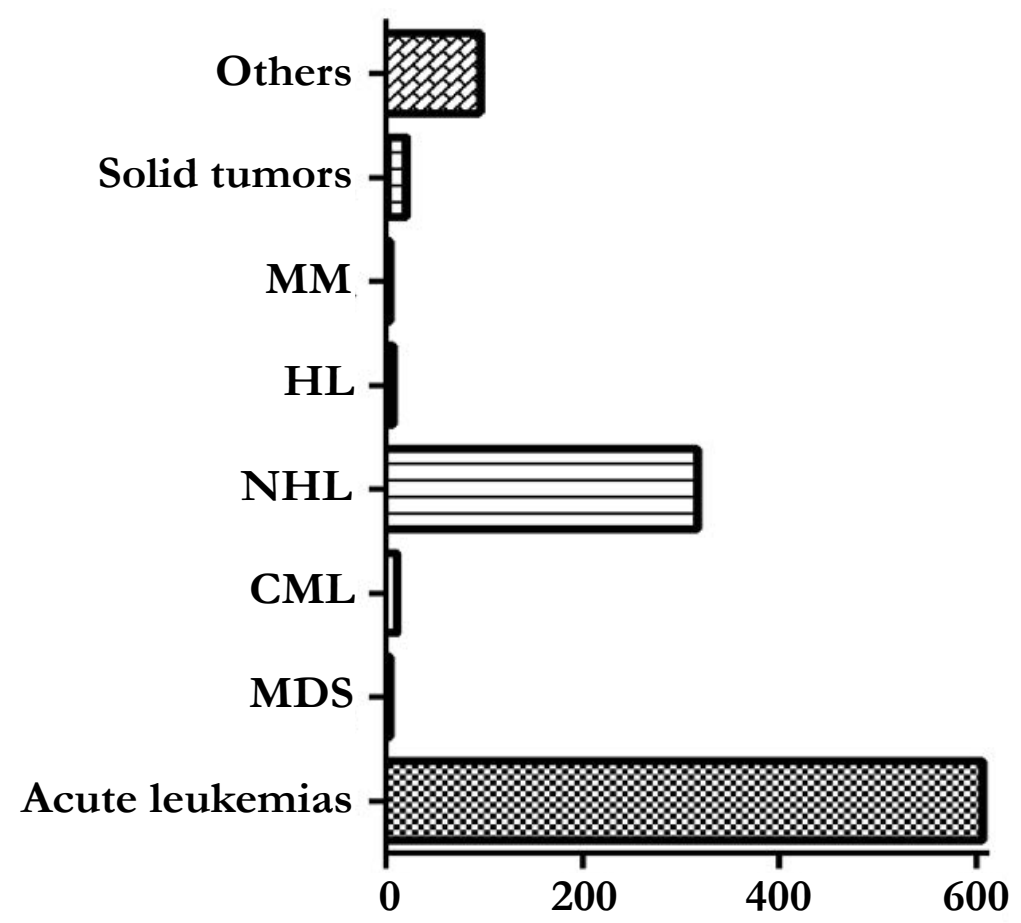

Fig. 4. Case distribution according to clinical suspicion. MDS: myelodysplastic syndrome; CML: Chronic Myelogenous Leukemia: NHL: Non-Hodgkin Lymphomas; HL: Hodgkin lymphoma; MM: multiple myeloma. 
Table 1. Antibody panel design according to clinical suspicion. Abbreviations: Cy, cytoplasmic antigen; $\mathrm{n}$, nuclear antigen; FITC, fluorescein isothiocyanate; PE, phycoerythrin; PerCP, peridinin-chlorophyllprotein; PECY7, PE cyanin (Cy)7; APC, allophycocyanin; APC7, APC- cyanin (Cy)7; NHL: Non Hodgkin Lymphomas; B-ALL: B cell acute lymphoblastic leukemia; AML: acute myeloblastic leukemia; T-ALL: T cell acute lymphoblastic leukemia; MDS: myelodysplastic syndromes; Others: HIV+ patients, patients with neurological symptoms, autoimmune diseases, etc.

\begin{tabular}{cccccccc}
\hline $\begin{array}{c}\text { Clinical } \\
\text { question }\end{array}$ & FITC & PE & PERCP & PECY7 & APC & APCCY7 & Beads \\
\hline B-NHL & Lambda & Kappa & CD19 & CD3 & CD14 & CD45 & + \\
\hline T-NHL & CD8 & CD4 & CD19 & CD3 & CD14 & CD45 & + \\
\hline HL & CD30 & CD200 & CD3 & CD38 & CD14 & CD45 & + \\
\hline B-ALL & CD34/nTdT & CD10 & CD19 & CD3 & CD14 & CD45 & + \\
\hline AML & CD34 & CD117 & CD19 & CD3 & CD14 & CD45 & + \\
\hline T-ALL & CD7/nTdT & CD5 & CD34 & CD3 & CD14 & CD45 & + \\
\hline MDS & CD34 & CD117 & CD19 & CD3 & CD14 & CD45 & + \\
\hline MM & cyLambda & cyKappa & CD19 & CD38 & CD138 & CD45 & + \\
\hline $\begin{array}{c}\text { Solid } \\
\text { tumors }\end{array}$ & CD34 & CD56/ & CD3 & CD38 & CD14 & CD45 & + \\
\hline Others & Lambda & Kappa & CD19 & CD3 & CD14 & CD45 & + \\
\hline & CD8 & CD4 & CD19 & CD3 & CD14 & CD45 & + \\
\hline
\end{tabular}

Analysis of pleural fluid samples

Pleural fluid samples (95) were assessed for B-NHL (56\%) tumor infiltration, followed by cases classified as "other," including infectious diseases, solid tumors, cytopenias, $\mathrm{HIV}+$ cases and pleural effusions, representing $21 \%$ of the total pleural fluid samples assayed (Figure 5C). After an analysis of these cases, it was found that $48(51 \%)$ were infiltrated by tumor cells, while the remaining 47 cases (49\%) were negative for tumor infiltration (Figure 5D). In samples with tumor infiltration, FCM detected a minimum of 0.1 tumor cells $/ \mu \mathrm{L}$. Pleural fluids with tumor infiltration showed a significantly higher absolute number of total cells compared with cases without tumor infiltration. In these samples, varying numbers of neutrophils, monocytes, macrophages, T lymphocytes, B lymphocytes, NK cells, plasma cells, dendritic cells and eosinophils were also detected (Table 2). Examples of pleural fluid analyses with and without tumor infiltration are shown in Figures 9. 
Table 2. Normal and tumor cell populations in special samples. NA, not applicable; NS: not significant.

\begin{tabular}{|c|c|c|c|c|c|}
\hline \multirow{2}{*}{$\begin{array}{l}\text { Type of sample } \\
\text { Cerebrospinal fluid }\end{array}$} & \multicolumn{2}{|c|}{ Normal/reactive } & \multicolumn{2}{|c|}{ Tumor infiltration } & \multirow[t]{2}{*}{$P$ value } \\
\hline & median & range & median & range & \\
\hline Number of cells $/ \mu \mathrm{L}$ & 16 & 0 to 3.022 & 151 & 0.06 to 4.816 & $<0.01$ \\
\hline Blast cells $/ \mu \mathrm{L}$ & - & - & 71 & 0.01 to 1.683 & NA \\
\hline Pathological B lymphocytes/ $\mu \mathrm{L}$ & - & - & 46 & 0.01 to 638 & NA \\
\hline Pathological T lymphocytes/ $\mu \mathrm{L}$ & - & - & 0,06 & - & NA \\
\hline T lymphocytes $/ \mu \mathrm{L}$ & 8 & 0 to 1.873 & 50 & 0.02 to 1.940 & $<0.01$ \\
\hline Monocytes $/ \mu \mathrm{L}$ & 3.7 & 0 to 979 & 35 & 0 to 3.477 & $<0.01$ \\
\hline Neutrophils/ $\mu \mathrm{L}$ & 26 & 0 to 1.820 & 57 & 0.03 to 1.277 & 0.01 \\
\hline Pleural fluid & median & range & median & range & $P$ value \\
\hline Number of cells $/ \mu \mathrm{L}$ & 743 & 1.1 to 6.166 & 1648 & 0.5 to 1.1981 & 0.08 \\
\hline Blast cells $/ \mu \mathrm{L}$ & - & - & 432 & 0.02 to 3.214 & NA \\
\hline Pathological B lymphocytes/ $\mu \mathrm{L}$ & - & - & 1068 & 2 to 9.788 & NA \\
\hline Pathological T lymphocytes/ $\mu \mathrm{L}$ & - & - & 360 & 298 to 423 & NA \\
\hline Pathological plasma cells/ $\mu \mathrm{L}$ & - & - & 1.174 & 52 to 2.295 & NA \\
\hline $\begin{array}{l}\text { Pathological CD } 45 \text { - cells } / \mu \mathrm{L} \\
\text { (solid tumors) }\end{array}$ & - & - & 137 & 0.8 to 671 & NA \\
\hline CD30+ cells $/ \mu \mathrm{L}(\mathrm{HL})$ & - & - & 0.02 & - & NA \\
\hline T lymphocytes/ $\mu \mathrm{L}$ & 366 & 0.4 to 4.932 & 371 & 0.08 to 3.399 & NS \\
\hline B lymphocytes/ $\mu \mathrm{L}$ & 81 & 0.01 to 739 & 76 & 0 to 1.580 & NS \\
\hline $\mathrm{NK}$ cells $/ \mu \mathrm{L}$ & 30 & 0.07 to 393 & 12 & 0.07 to 47 & NS \\
\hline Monocytes $/ \mu \mathrm{L}$ & 91 & 0.04 to 471 & 163 & 0.08 to 2.778 & NS \\
\hline Neutrophils/ $\mu \mathrm{L}$ & 197 & 0.06 to 2.179 & 254 & 0.3 to 2.932 & NS \\
\hline Dendritic cells $/ \mu \mathrm{L}$ & 29 & - & 2.9 & - & NA \\
\hline Macrophages/ $\mu \mathrm{L}$ & 83 & 0.8 to 352 & 20 & 1.4 to 41 & NS \\
\hline Bronchoalveolar lavage & median & range & median & range & $P$ value \\
\hline Number of cells/ $\mu \mathrm{L}$ & 930 & 0.6 to 16.087 & 161 & 8 to 603 & NA \\
\hline Blast cells $/ \mu \mathrm{L}$ & - & - & 0.9 & 0.1 to 2 & NA \\
\hline Pathological B lymphocytes/ $\mu \mathrm{L}$ & - & - & 69 & 0.1 to 138 & NA \\
\hline T lymphocytes/ $\mu \mathrm{L}$ & 24 & 0.1 to 149 & 76 & 2.4 to 313 & NS \\
\hline B lymphocytes/ $\mu \mathrm{L}$ & 0.5 & - & 3 & 0.1 to 6 & NS \\
\hline $\mathrm{NK}$ cells $/ \mu \mathrm{L}$ & 1.2 & 0.4 to 2 & 3.3 & 0.5 to 6 & NS \\
\hline Monocytes $/ \mu \mathrm{L}$ & 80 & 0.1 to 563 & 58 & 0.3 to 118 & NS \\
\hline Macrophages/ $\mu \mathrm{L}$ & 88 & 34 to 141 & 62 & - & NA \\
\hline Neutrophils/ $\mu \mathrm{L}$ & 1.205 & 0.7 to 15.475 & 7.7 & 0.2 to 18 & NS \\
\hline
\end{tabular}




\section{Analysis of bronchoalveolar lavage (BAL)}

Broncho alveolar lavage samples [24] were studied in order to detect infiltration by B-NHL (46\% of cases) and B-ALL (17\% of cases). Within the "other" category $(17 \%)$ were samples from patients with sarcoidosis and lymphadenopathy (Figure 4E). After analysis, tumor infiltration was detected in $21 \%$ of the samples (Figure $4 \mathrm{~F}$ ). For positive cases, FCM detected a minimum of 0.1 tumor cells $/ \mu \mathrm{L}$.

In these samples, varying numbers of neutrophils, monocytes and macrophages, T lymphocytes, B lymphocytes, NK cells, plasma cells, dendritic cells and eosinophils were also determined.

A

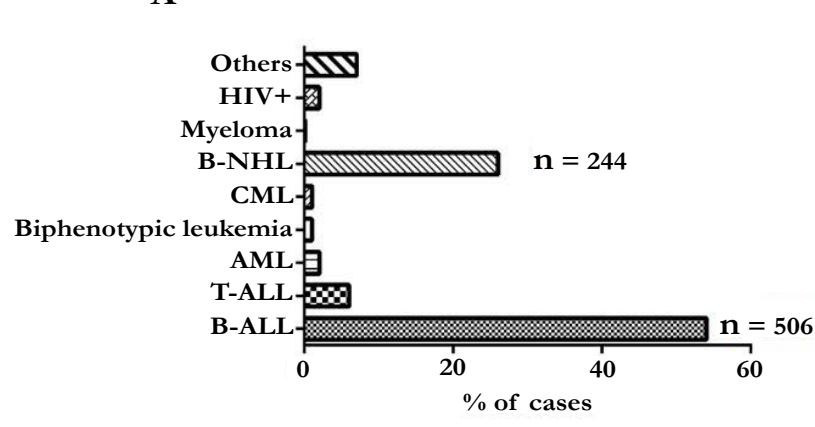

C

Others - $\mathrm{n}=20$

Myeloma- $\rightarrow$

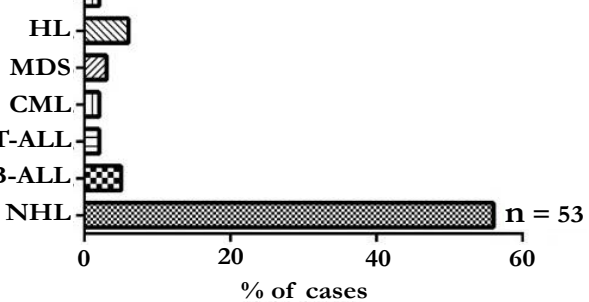

B

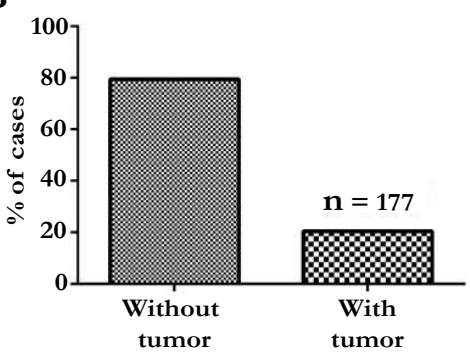

Pleural fluid

D

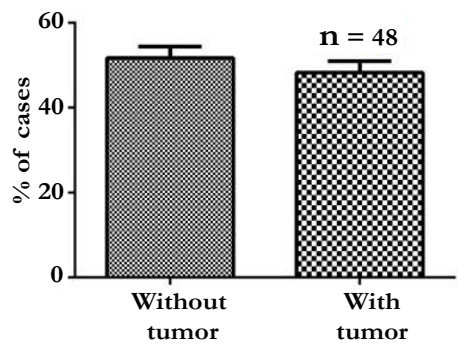

\section{Bronchoalveolar lavage}

$\mathbf{E}$

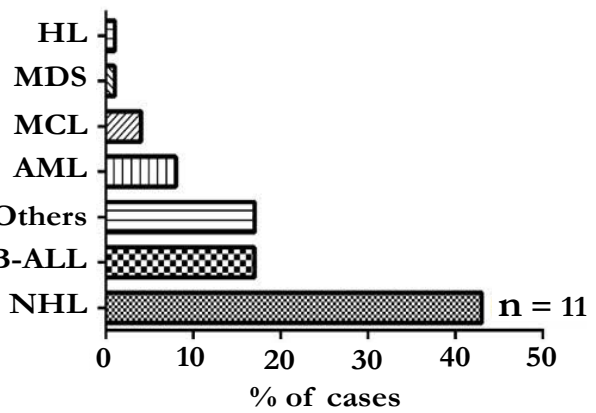

F

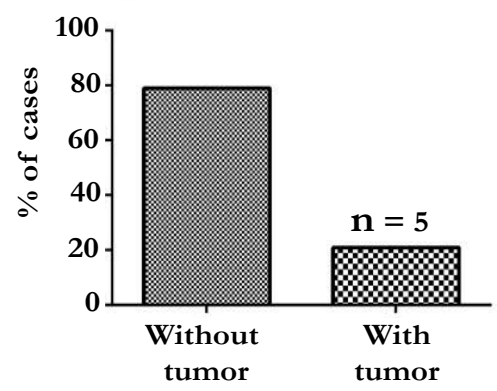

Fig. 4. Types of pathologies evaluated in body fluids samples (panels A, C and E) and tumor infiltration results (panels B, D and F). CSF: cerebrospinal fluid; HIV: human immunodeficiency virus, B-NHL: B-cell lymphoma, CML: chronic myeloid leukemia, AML: acute myeloid leukemia, B-ALL: acute lymphoblastic leukemia B; T-ALL: acute lymphoblastic leukemia T; LH: Hodgkin lymphoma. 


\section{Analysis of other special samples}

Pericardial fluid: Eight samples of pericardial fluid were analyzed to assess B-NHL at diagnosis $(\mathrm{n}=6)$, additionally a solid tumor and one case of systemic lupus erythematosus (SLE). All samples were negative for tumor infiltration. T lymphocytes and monocytes were detected in $100 \%$ of the samples. Additionally, neutrophils (7/8 cases), B-lymphocytes (6/8 cases), NK cells (5/8 cases) and plasma cells (4/8 cases) were also detected. The average total cell number was $304 / \mu \mathrm{L}$ (range: 4.5 cells $/ \mu \mathrm{L}$ to 762 cells $/ \mu \mathrm{L}$ ).

Peritoneal fluid: Seven samples of peritoneal fluid were analyzed in patients with multiple myeloma $(n=2)$, B-NHL $(n=2)$, carcinoma $(n=1)$ and anemia $(n=1)$. Of these, only one case of myeloma was positive for tumor infiltration. An analysis of cellularity revealed that T lymphocytes were detected in $100 \%$ of patient samples, while NK cells and monocytes were detected in 6/7 cases, B-lymphocytes and

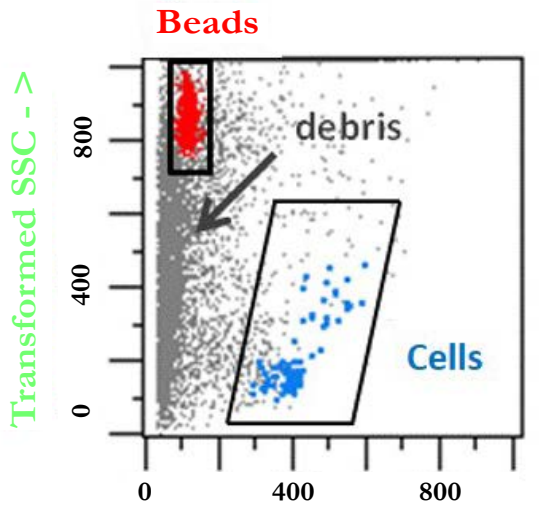

FSC-H - >

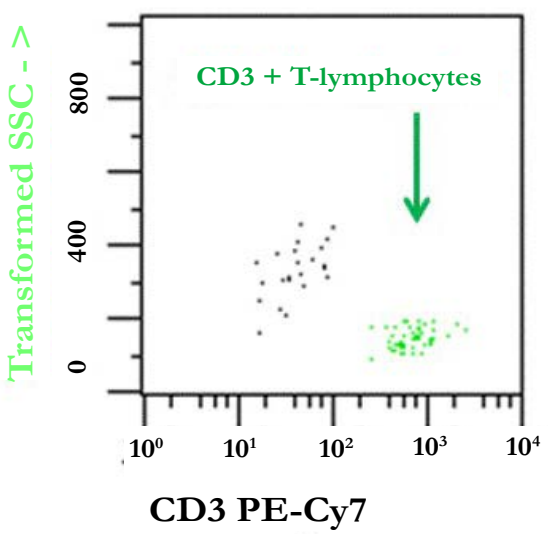

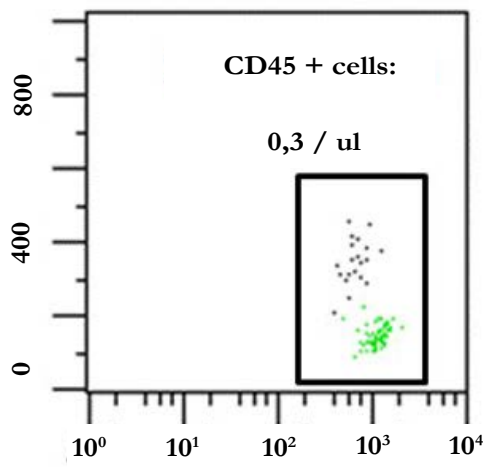

CD45 APC-Cy7

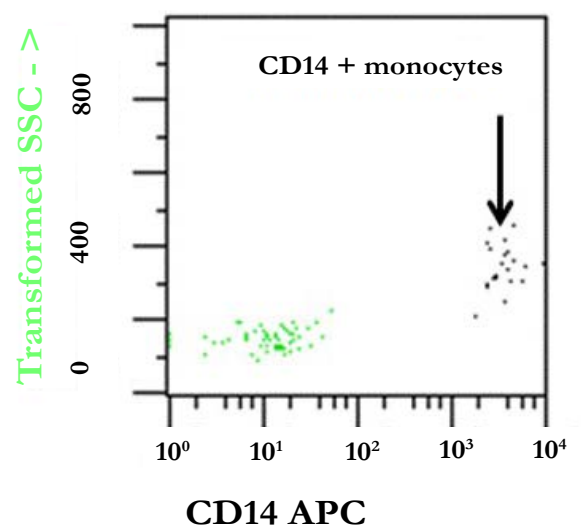

Fig. 5. Representative result of bivariate dot plot histograms of a normal/reactive CSF sample from a B-cell lymphoma patient showing no CSF infiltration by multiparameter flow cytometry immunophenotyping. In this sample, CD3+/CD45+ T cells (green dots) and CD14+/CD45 + monocytes (black dots) were detected. Gray dots represent non leukocyte events (debris) and red dots correspond to fluorescent beads. 
neutrophils were detected in 5/7 and eosinophils and macrophages were detected in $1 / 7$ cases. The average number of cells detected was $2017 / \mu \mathrm{L}$ with a range of 0.2 cells $/ \mu \mathrm{L}$ to 10780 cells $/ \mu \mathrm{L}$. The myeloma sample with tumor infiltration had 2811 pathological plasma cells $/ \mu \mathrm{L}$, which represented $92 \%$ of the total cellularity.

Synovial fluid: One sample was analyzed for the study of MDS during clinical monitoring of the disease. This sample had 2.6 myeloid blasts $/ \mu \mathrm{L}$, which was equivalent to $7.6 \%$ of the total cellularity. T and B lymphocytes and monocytes were also detected. Total cell number was 34 cells $/ \mu \mathrm{L}$.
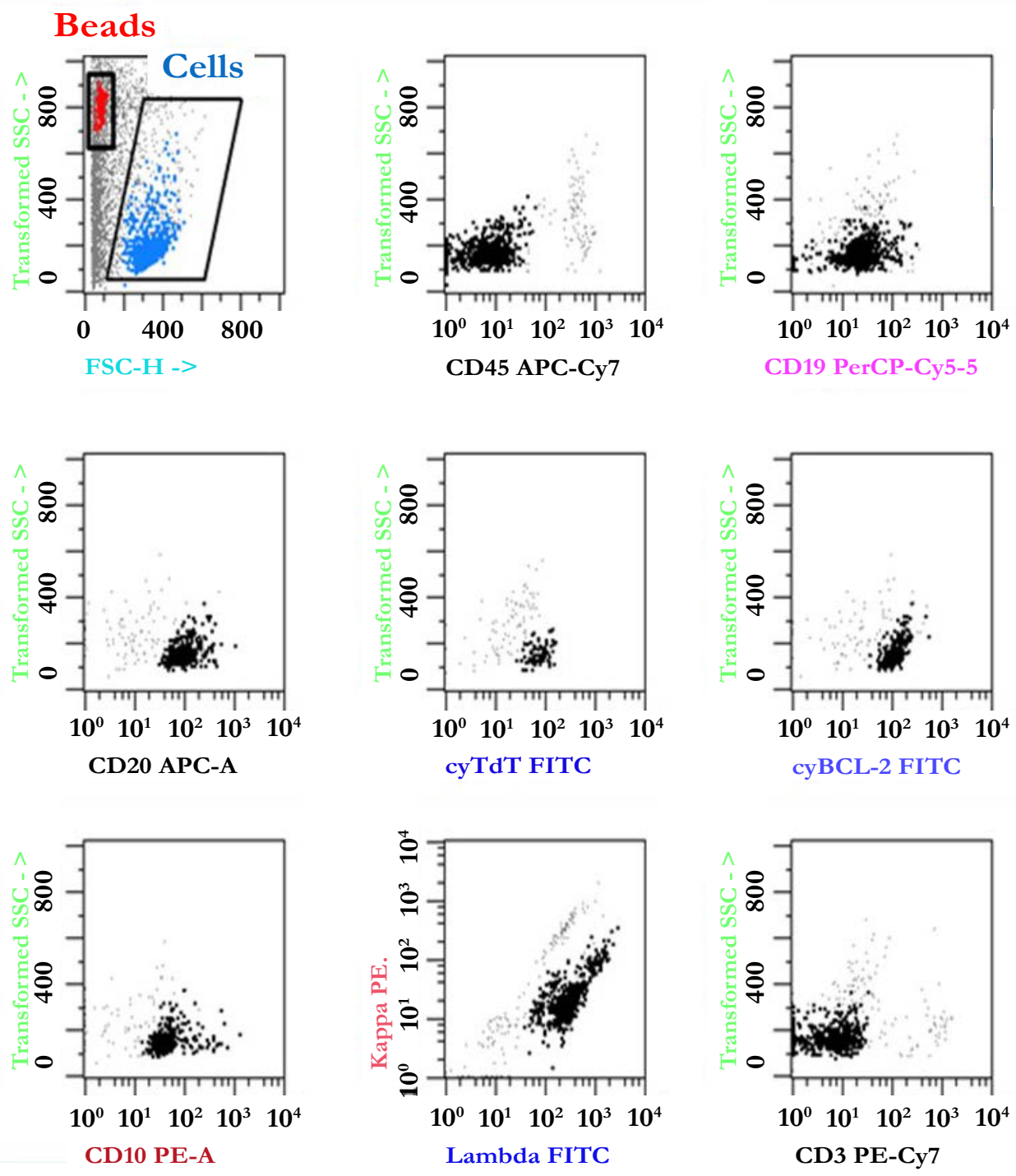

\begin{tabular}{|lllll|}
\hline \multicolumn{4}{|c|}{ Pathological B lymphocytes: 88,3 \% (5/ul) } & \\
CD45- & CD19+ & CD20+ & TdT+ & Bcl-2+ \\
CD10+ & Kappa- & Lambda+ & CD3- & \\
\hline
\end{tabular}

Fig. 6. Identification of B tumor cells in a representative CSF sample from a B-lymphoblastic lymphoma patient. Events enclosed in red identify beads and events enclosed in blue identify total cells. Lymphoma cells (black dots) are positive for CD19, CD20, TdT, Bcl-2 and CD10. Analysis of clonality revealed monoclonal restriction of lambda light chain. Tumor cell count: $5 / \mu \mathrm{L} ; 88.3 \%$. 
Ascites: Three samples of ascitic fluid were analyzed, two for the study of B-NHL infiltration and the other for the study of an infectious process. The two cases of B-NHL were negative for tumor infiltration. For all three samples, T lymphocytes, monocytes, B-lymphocytes, NK cells and neutrophils were detected, while plasma cells were detected in two samples. The average total number of cells was $1680 / \mu \mathrm{L}$ with a range of 917 cells $/ \mu \mathrm{L}$ to 2659 cells $/ \mu \mathrm{L}$.

\section{Discussion}

In recent years, one diagnostic tool that has become very important in clinical practice is FCM immunophenotyping, providing higher sensitivity and efficiency. Therefore, allowing simultaneous analysis of multiple features, compared with other cell analytical
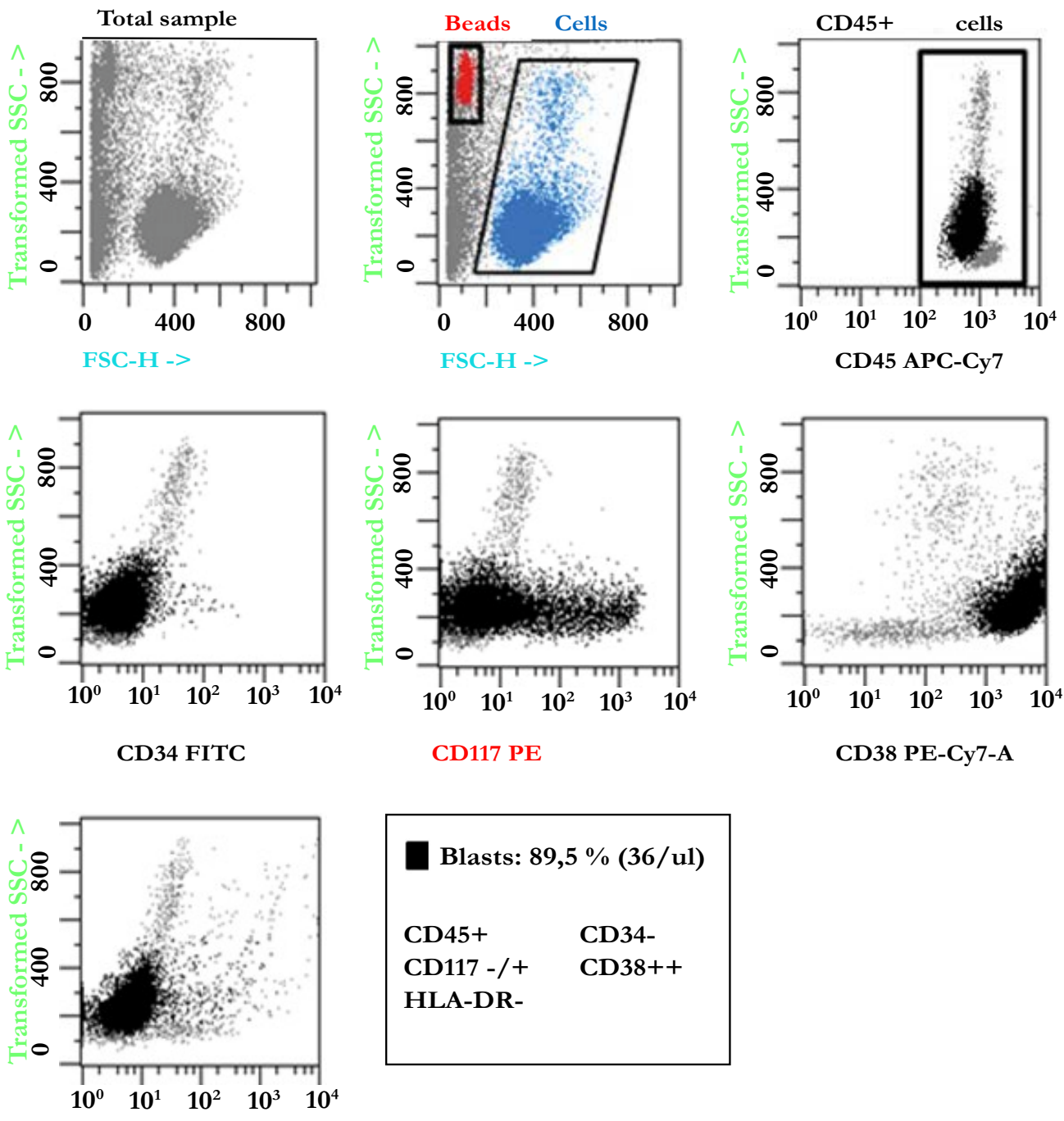

Blasts: 89,5 \% (36/ul)

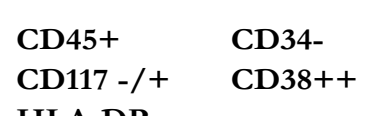

HLA-DR-

CD10 PE-A

Fig. 7. Illustrative example of a CSF sample from a blast crisis in a patient with chronic myeloid leukemia. For analysis, beads (red dots) and cells (blue dots) are selected. Black dots represent a large population $(89.5 \%)$ of myeloid blasts with expression of CD45, CD117 and CD38. Blast cell count: $36 / \mu \mathrm{L}$. 

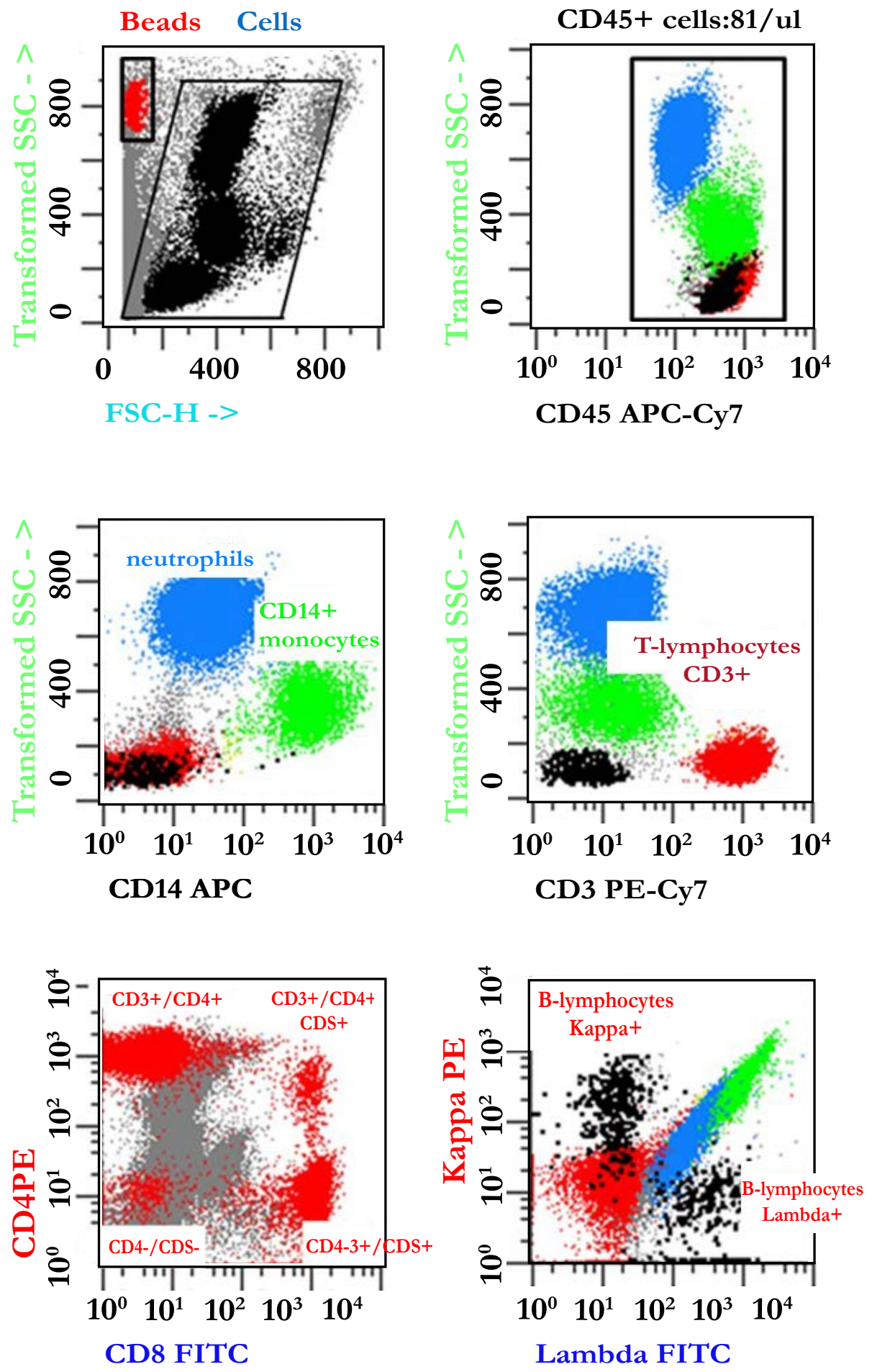

Fig. 8. Illustrative example of the immunophenotypic analysis of leukocyte populations present in normal pleural fluid. For analysis, beads (red dots) and leukocytes (black dots) were selected by gating on Side Scatter -SSC- vs. Forward Scatter -FSC. Next, CD45+ leukocytes were defined by plotting events in a CD45 versus SSC dot plot. Based on differences in their physical parameters, neutrophils (blue dots), monocytes (CD14+ green dots), T lymphocytes (CD3+, CD4+ or CD8+ red dots) and B lymphocytes (black dots) exhibited polyclonal expression of Kappa/Lambda light chains. Total leukocyte count: $81 / \mu \mathrm{L}$. 

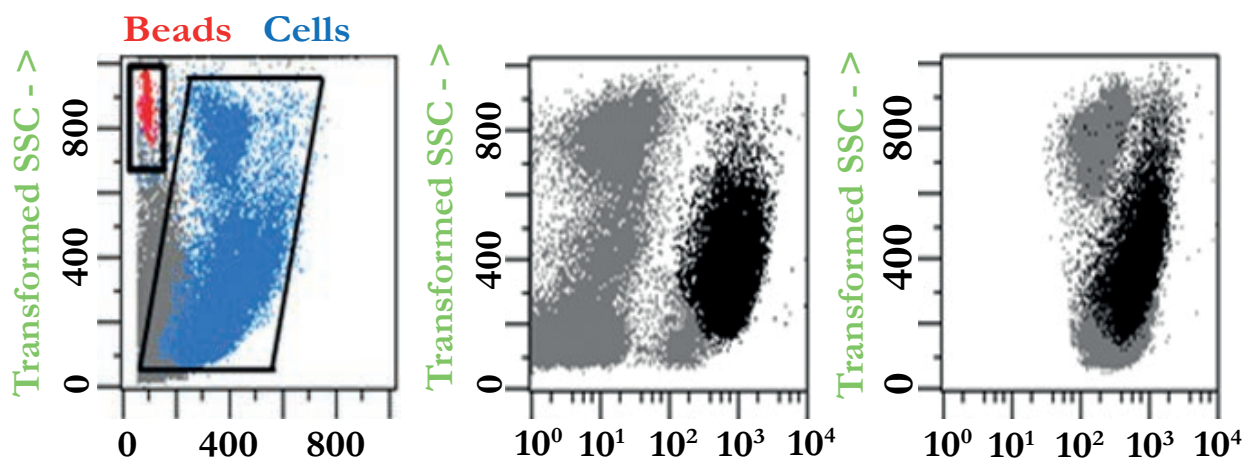

FSC-H ->

CD19 PerCP-Cy5-5

CD45 APC-Cy7

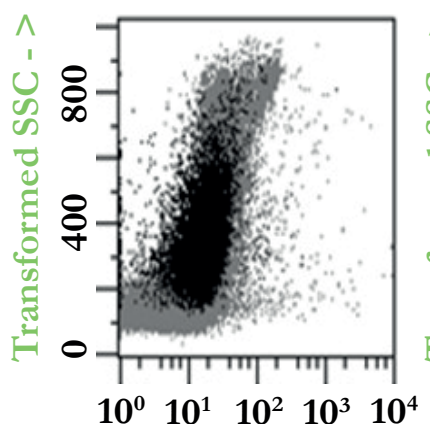

CD10 PE

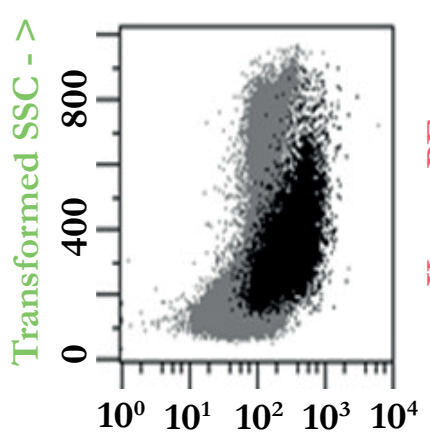

cyBCL-2 FITC

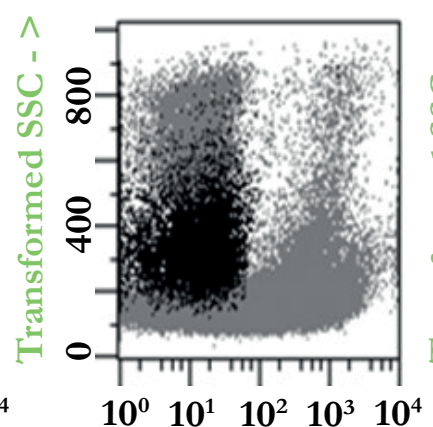

CD38 PE-Cy7-A

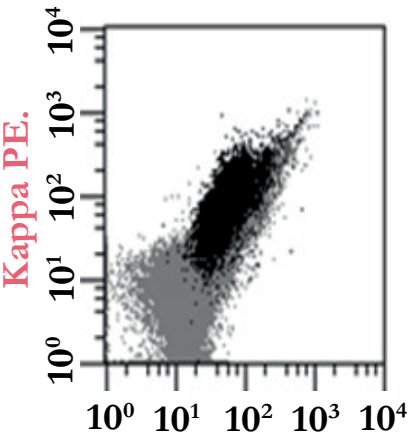

Lambda FITC

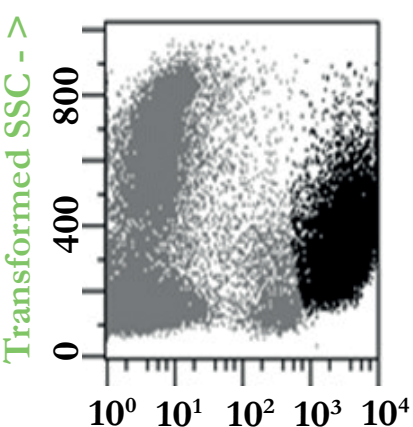

CD20 APC

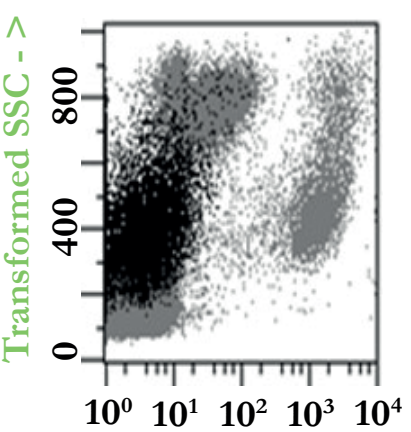

CD14 APC

Pathological B lymphocytes: $19 \%$ (94/ul)

$\begin{array}{lllll}\mathrm{CD} 19+ & \mathrm{CD} 45+ & \mathrm{CD} 10- & \mathrm{CD} 38- & \mathrm{CD} 20+ \\ \mathrm{Bcl}-2+ & \mathrm{Kappa}+ & \text { Lambda- } & \text { CD14- } & \end{array}$

Fig. 9. Example of a pleural fluid sample from a B lymphoma patient with a monoclonal B population with kappa light chain restriction blast. These cells were also positive for CD19, CD45, and CD20. Events encircled in red identify beads and events encircled with blue identify total cells. Tumor cell count: $94 / \mu \mathrm{L} ; 19 \%$. 
techniques. Currently, antibody panels with eight to ten types of fluorescence are used, which give information on cell lineage, maturation stages, aberrant phenotypes and absolute and relative numbers of normal and tumor cells $[1-2,6]$.

Biological sample flow cytometry analysis for the diagnosis and follow-up is very important in routine clinical practice for classification, and monitoring of diseases in conjunction with morphological and molecular analysis [15]. Immunophenotyping has provided relevant information for the diagnosis, classification and monitoring of hematological malignancies and other diseases [2]. Consequently, assessment of immunophenoype by FCM has become essential and is part of the current World Health Organization (WHO) classification of hematological malignancies [16 - 18].

In 2006 the European Union-supported the EuroFlow Consortium (EU-FP6, LSHB-CT-2006-018708). This project aimed at the prospective design and evaluation of antibody panels for haematological disease diagnosis and classification, where immunophenotyping was proven relevant [17 - 18]. EuroFlow has contributed in the development of highly sensitive and standardized FCM; particularly in the study of acute leukemias and lymphomas. These protocols describe optimal antibody panels, design and evaluation of adequate standard operating procedures (SOPs) for instrument setup, fluorescence compensation, and sample preparation. Furthermore, elaboration of adequate software tools for overall evaluation of obtained phenotypic profiles [17 - 18]. These advances have significantly improved minimal residual disease (MRD), detection, assessing therapy response. Moreover, it is considered an important prognostic indicator [18].

Many advantages have been reported for FCM in the study of various types of biological samples such as BM, PB and special samples, including tissue biopsies and body fluids (pleural fluid, pericardial fluid, and CSF, among others, have been reported). Additionally, flow cytometric immunophenotyping has sustained its position as an indispensable tool, as demonstrated by recent studies from the European Consortium EuroFlow. One advantage has been vitreous sample assessment for the study of tumor infiltration by intraocular lymphomas and central nervous system lymphomas $[1-2,6]$. Therefore, it is vital to ensure sample quality at the pre-analytical phase, to maintain cell viability and cellular antigen integrity [6]. Some samples evaluated by flow cytometry must be processed within 24 hours, in particular BM and PB. However, other samples such as body fluids and biopsies undergo greater damage over time. It has been reported cell death percentages may increase over $80 \%$ between 30 min to $6 \mathrm{~h}$ after the sample collection $[2,6,13]$.

In order to obtain better quality samples at the pre-analytical phase, use of commercially available stabilizing solutions has been implemented within the last decade. Examples include Transfix ${ }^{\mathrm{TM}}$ (Cytomark, Buckingham, UK) and Cyto-Chex BCT (Streck, Omaha, NE, USA), both validated for clinical use [2, 4, 13, 19 - 22]. Different studies have reported that PB samples treated with these stabilizers and evaluated at different times post-incubation display increased cell viability and maintenance of cell structures, which provides more reliable results directly reflecting the actual status of the patient [19 - 21, 23 - 24].

Some studies by different groups have focused on the effect of Transfix ${ }^{\mathrm{TM}}$ as a stabilizer evaluation, reporting various technical indications for its use (Table 3) [25]. 
Table 3. Technical indications for TransFix ${ }^{\mathrm{TM}}$ stabilizer use (López D 2012).

Variable

\begin{tabular}{|c|c|}
\hline Preparation & $\begin{array}{l}\text { TransFix }{ }^{\mathrm{TM}} \text { is added to whole sample at a ratio of } 200 \mu \mathrm{L} \\
\text { per } \mathrm{ml}(1: 5) .\end{array}$ \\
\hline Physical appearance of the reagent & $\begin{array}{l}\text { Normal appearance of TransFix }{ }^{\mathrm{TM}} \text { is that of a clear pale } \\
\text { green liquid. }\end{array}$ \\
\hline Storage & $\begin{array}{l}\text { At room temperature }\left(18-24^{\circ} \mathrm{C}\right) \text {. TransFix }{ }^{\mathrm{TM}} \text { must not be } \\
\text { stored at } 4^{\circ} \mathrm{C} \text {. }\end{array}$ \\
\hline Evidence of Deterioration & $\begin{array}{l}\text { Any change in the physical appearance of the reagent may } \\
\text { indicate deterioration. }\end{array}$ \\
\hline Type of sample & $\begin{array}{l}\text { It can be used for PB, cord blood, CSF and bone marrow } \\
\text { samples. }\end{array}$ \\
\hline Type of anticoagulant used & $\begin{array}{l}\text { TransFix }{ }^{\mathrm{TM}} \text { can be used with all commonly used } \\
\text { anticoagulants (K3EDTA, citrate, etc.). }\end{array}$ \\
\hline Storage and stability & $\begin{array}{l}>4^{\circ} \mathrm{C} \text { : The sample is suitable for up to } 10 \text { days after } \\
\text { collection. } \\
>18^{\circ} \mathrm{C}-24^{\circ} \mathrm{C} \text { : Preservation until } 7 \text { days after collection. } \\
>37^{\circ} \mathrm{C} \text { : Stability up to } 3 \text { days. }\end{array}$ \\
\hline Types of analysis & $\begin{array}{l}\text { Immunophenotype by flow cytometry. } \\
\text { Counts of lymphocyte subpopulations, etc. }\end{array}$ \\
\hline
\end{tabular}

\section{Technical Instructions for Use}


in granulocytes and lymphocytes. They showed that CD45 expression was altered by dilutional effects [26]. Moreover, PB cell morphology evaluation by transmission electron microscopy (TEM) evidenced after ten d of storage in Transfix ${ }^{\mathrm{TM}}$ and sample incubation at different temperatures $\left(4^{\circ} \mathrm{C}, 25^{\circ} \mathrm{C}\right.$ and $\left.37^{\circ} \mathrm{C}\right)$, lymphocytes retained their morphology compared to other cell types [26].

Other studies have reported Transfix ${ }^{\mathrm{TM}}$ use in the study and monitoring of central nervous system infiltration in patients with aggressive lymphomas and acute leukemias. In these studies, Transfix ${ }^{\mathrm{TM}}$ was suggested to enhance CSF hematological malignancies detection by preventing cellular loss after $10 \mathrm{~d}$ of storage $[2,4,7,10$, $12-13,27]$.

Although Transfix ${ }^{\mathrm{TM}}$ in flow cytometry clinical application has already been reported in various studies, no consensus has been reached on its implementation in clinical practice. Moreover, other studies to evaluate its use in samples other than PB and CSF have not been conducted [28 - 29]. In the first Colombian Flow Cytometry Consensus of 2008, it was recommended that samples of body fluids be stabilized in case they not processed during the maximum recommended times [6]. It is for this reason that from 2008 onwards, all body fluids samples from patients with different pathologies (both benign and malignant diseases) are collected into tubes containing Transfix ${ }^{\mathrm{TM}}$.

Results from the analysis of 1070 samples over a period of $6 \mathrm{y}$, demonstrate the medical community and patients have significantly benefitted from the implementation of this tool for the study of special samples. These samples are of a greater quality and hence, allow a better classification and staging, with important implications at the therapeutic level for clinical disease monitoring and prognosis. We note that most special samples processed and analyzed corresponded to CSF from patients who were diagnosed with B-ALL. These samples were obtained at different time points during the disease process and have great applicability with other pathologies including other hematological malignancies, solid tumors and other diseases.

Additionally, for all samples tested it is shown that FCM is a tool with great sensitivity. It can detect minute quantities of tumor cells at least 0.01 cells $/ \mu \mathrm{L}$ in CSF samples and 0.1 cells $/ \mu \mathrm{L}$ in other samples evaluated for cases with tumor infiltration. Flow cytometry can also detect small numbers of normal cells in various body fluids with and without tumor infiltration in a wide range of diseases. It is important to note that in these cases, rare normal cell populations, such as dendritic cells in the pleural fluid, were also detected [1].

For autoimmune diseases, immunodeficiency, infectious diseases and inflammatory processes, FCM is useful for sample cellularity description, as it identifies populations of T lymphocytes, B-lymphocytes, NK cells, plasma cells, eosinophils, basophils, and macrophages, among other cell types [1].

This work represents the first report at the national level supporting Transfix ${ }^{\mathrm{TM}}$ implementation in pre-analytical FCM studies of all body fluids that are processed in the clinical practice. In addition, it recommends flow cytometric immunophenotyping as an indispensable tool in our country's laboratories to guarantee quality results for the benefit of our patients. 


\section{Acknowledgments}

The authors appreciate the financial support provided by the Pontificia Universidad Javeriana and Hospital Universitario San Ignacio.

\section{Conflict of Interest}

The authors declare no conflicts of interest exist in relation to this work.

\section{References}

1. Jaye DL, Bray RA, Gebel HM, Harris W, Waller EK. Translational Applications of Flow Cytometry in Clinical Practice, Journal of Immunology, 188: 4715 - 4719, 2012.

doi: 10.4049/jimmunol.1290017

2. Van Dongen JJM, Lhermitte L, Bottcher S, Almeida J, van der Velden VHJ, Flores-Montero J, et al. EuroFlow antibody panels for standardized n-dimensional flow cytometric immunophenotyping of normal, reactive and malignant leukocytes, Leukemia, 26: 1908 - 1975, 2012.

doi: 10.1038/leu.2012.120

3. Subirá D, Simó M, Illán J, Serrano C, Castañón S, Gonzalo R, et al. Diagnostic and prognostic significance of flow cytometry immunophenotyping in patients with leptomeningeal carcinomatosis, Clinical \& Experimental Metastasis, 32: 383 - 9, 2015.

doi: 10.1007/s10585-015-9716-3

4. Quijano S, López A, Manuel SJ, Panizo C, Deben G, Castilla C, et al. Identification of leptomeningeal disease in aggressive B-cell non-hodgkin's lymphoma: improved sensitivity of flow cytometry, Journal of Clinical Oncology, 27: 1462 - 69, 2009.

doi: 10.1200/JCO.2008.17.7089

5. Kraan J, Gratama JW, Haioun C, Orfao A, Plonquet A, Porwit A, et al. Flow cytometric immunophenotyping of cerebrospinal fluid, Current Protocols in Citometry, Supplement 45: $6.25 .1-6.25 .16,2008$.

doi: 10.1002/0471142956.cy0625s45

6. Saavedra C, Quijano S, Romero M, Jaramillo R, Orduz R, Echeverri C, et al. Reporte del Primer Consenso Colombiano de Citometría de Flujo para el estudio de trastornos hematológicos, Biomédica, 30 (Supl): 11 - 21, 2010.

doi: 10.7705/biomedica.v30i0.818

7. Ranta S, Nilsson F, Harila-Saari A, Saft L, Tani E, Söderhäll S, et al. Detection of Central Nervous System Involvement in Childhood Acute Lymphoblastic Leukemia by Cytomorphology and Flow Cytometry of the Cerebrospinal Fluid, Pediatric Blood \& Cancer, 62: 951 - 956, 2015.

doi: 10.1002/pbc.25363

8. de Graaf MT, de Jongste AH, Kraan J, Boonstra JG, Sillevis, Smitt PA, et al. Flow cytometric characterization of cerebrospinal fluid cells, Cytometry part B Clinical Cytometry, 80(5): 271 - 278, 2011.

doi: 10.1002/cyto.b.20603

9. Davis C, Wu X, Li W, Fan H, Reddy M. Stability of immunophenotypic markers in fixed peripheral blood for extended analysis using flow cytometry, Journal of Immunological Methods, 363(2): 158 - 165, 2011.

doi: 10.1016/j.jim.2010.09.029 
10. Del Principe M, Buccisano F, Cefalo M, Maurillo L, Di Caprio L, Di Piazza F, et al. High sensitivity of flow cytometry improves detection of occult leptomeningeal disease in acute lymphoblastic leukemia and lymphoblastic lymphoma, Annals of Hematology, 93(9): 1509 - 1513, 2014.

doi: 10.1007/s00277-014-2080-6

11. Bromberg JE, Breems DA, Kraan J, Bikker G, van der Holt B, Smitt PS, et al. CSF flow cytometry greatly improves diagnostic accuracy in CNS hematologic malignancies, Neurology, 68(20): 1674 - 1679, 2007.

doi: 10.1212/01.wnl.0000261909.28915.83

12. Ahluwalia MS, Wallace P K, Peereboom D M. Flow cytometry as a diagnostic tool in lymphomatous or leukemic meningitis, Cancer, 118(7): 1747 - 1753, 2012.

doi: $10.1002 /$ cncr.26335

13. de Jongste AH, Kraan J, van den Broek PD, Brooimans RA, Bromberg JE, van Montfort $\mathrm{KA}$, et al. Use of TransFix ${ }^{\mathrm{TM}}$ cerebrospinal fluid storage tubes prevents cellular loss and enhances flow cytometric detection of malignant hematological cells after 18 hours of storage, Cytometry part B Clinical Cytometry, 86(4): 272 - 279, 2014.

doi: 10.1002/cyto.b.21097

14. Roa D, Fiorentino S, Rodríguez V, Campos A, Infante A, Cardozo C, et al. Análisis inmunofenotípico de muestras normales de médula ósea: aplicaciones en el control de calidad en los laboratorios de citometría, Universitas Scientiarum, 15: 206 - 223, 2010.

doi: 10.11144/javeriana.SC15-3.iaon

15. Seegmiller, Adam C, Steven H Kroft, Nitin J Karandikar, and Robert W McKenna. Characterization of Immunophenotypic Aberrancies in 200 Cases of B Acute Lymphoblastic Leukemia, American Journal of Clinical Patbology, 132(6): 940 - 949, 2009.

doi: 10.1309/AJCP8G5RMTWUEMUU

16. Swerdlow SH, Campo E, Pileri SA, Harris NL, Stein H, Siebert R, et al. The 2016 revision of the World Health Organization classification of lymphoid neoplasms, Blood, 127: 2375 - 90, 2016.

doi: 10.1182/blood-2016-01-643569

17. Kalina, T, J Flores-Montero, V H J van der Velden, M Martin-Ayuso, S Böttcher, M Ritgen, J Almeida, et al. EuroFlow Standardization of Flow Cytometer Instrument Settings and Immunophenotyping Protocols, Leukemia, 26(9): 1986 -2010, 2012.

doi: 10.1038/leu.2012.122

18. Cruz-Rodriguez N, Combita AL, Enciso LJ, Raney LF, Pinzon PL, Lozano OC, et al. Prognostic stratification improvement by integrating ID1/ID3/IGJ gene expression signature and immunophenotypic profile in adult patients with B-ALL, Journal of Experimental \& Clinical Cancer Research, 36: 37, 2017.

doi: 10.1186/s13046-017-0506-4

19. Saxton JM, Pockley AG. Effect of ex vivo storage on human peripheral blood neutrophil expression of $\mathrm{CD} 11 \mathrm{~b}$ and the stabilizing effects of Cyto-Chex, Journal of Immunological Methods, 214(1-2): 11 - 17, 1998.

doi: 10.1016/S0022-1759(98)00049-0

20. Warrino DE, DeGennaro LJ, Hanson M, Swindells S, Pirruccello SJ, Ryan WL. Stabilization of white blood cells and immunologic markers for extended analysis using flow cytometry, Journal of Immunological Methods, 305(2): 107 - 119, 2005.

doi: 10.1016/j.jim.2005.01.021 
21. Canonico B, Zamai L, Burattini S, Granger V, Mannello F, Gobbi P, et al. Evaluation of leukocyte stabilisation in TransFix-treated blood samples by flow cytometry and transmission electron microscopy. J Immunol Methods. 2004; 295: 67 - 78.

22. Schumacher A. Effect of ex vivo storage and Cyto-Chex on the expression of P-selectin glycoprotein ligand-1 (PSGL-1) on human peripheral leukocytes, Journal of Immunological Methods, 323(1): 24 - 30, 2007.

doi: $10.1016 /$ j.jim.2007.03.004

23. Jani IV, Janossy G, Iqbal A, Mhalu FS, Lyamuya EF, Biberfeld G, et al. Affordable CD4+ T cell counts by flow cytometry: II. The use of fixed whole blood in resource-poor settings, Journal of Immunological Methods, 257(1 - 2): 145 - 54, 2001.

doi: 10.1016/S0022-1759(01)00458-6

24. Bergeron M, Shafaie A, Ding T, Phaneuf S, Soucy N, Mandy F, et al. Evaluation of stabilized blood cell products as candidate preparations for quality assessment programs for CD4 T-cell counting, Cytometry, 50: 86 - 91, 2002.

doi: 10.1002/cyto.10090

25. López D. Efectos de los estabilizantes Transfix y Cyto-chex en muestras de sangre periférica, analizadas por citometría de flujo. Trabajo de grado Carrera Bacteriología, Facultad de Ciencias, Pontificia Universidad Javeriana. 2012.

Retrieved from: http://hdl.handle.net/10554/10410

26. Canonico B, Betti M, Francesca F, Battistelli M, Falcieri E, Ferri P, et al. Flow Cytometric Profiles, Biomolecular and Morphological Aspects of Transfixed Leukocytes and Red Cells, Cytometry Part B Clinical Cytometry, 78(4): 267 - 278, 2010.

doi: $10.1002 /$ cyto.b.20510

27. Sancho JM, Orfao A, Quijano S, García O, Panizo C, Pérez-Ceballos E, et al. Clinical significance of occult cerebrospinal fluid involvement assessed by flow cytometry in non-Hodgkin's lymphoma patients at high risk of central nervous system disease in the rituximab era, European Journal of Haematol, 85: 321 - 8, 2010.

doi: 10.1111/j.1600-0609.2010.01478.x

28. Ruiz A, Duque R and Orfao, A. Report on the first latin american consensus conference for flow cytometric immunophenotyping of leukemia, Cytometry, 34(1): 39 - 42, 1998

doi: 10.1002/(SICI)1097-0320(19980215)34:1<39::AID-CYTO7>3.0.CO;2-9

29. Ruiz A, Rivadeneyra L, Duque R, Orfao A. Report on the second latin american consensus conference for flow cytometric immunophenotyping of hematological malignancies, Cytometry part B Clinical Cytometry, 70B: 39 - 44, 2006.

doi: 10.1002/cyto.b.20083 
Estudio de muestras de fluidos corporales utilizando citometría de flujo: seis ańos de experiencia en el Hospital Universitario San Ignacio - Pontificia Universidad Javeriana Bogotá, Colombia

Resumen. La citometría de flujo fue implementada en 2008 en la Pontificia Universidad Javeriana y posteriormente en el Hospital San Ignacio con el fin de examinar, para diagnóstico y monitoreo, muestras especiales de pacientes con malignidades hematológicas y tumores sólidos, distintos de los de médula ósea y sangre periférica. Este estudio describe los principales hallazgos de la evaluación de estas muestras especiales en un periodo de seis años. En total, se examinaron por citometría de flujo 1070 muestras de fluidos corporales de pacientes con enfermedades malignas y benignas. Estas muestras se estabilizaron con TransFix ${ }^{\mathrm{TM}}$ y teñidas con paneles inmunofenotípicos de seis colores. Las muestras incluyeron líquido cefalorraquídeo, lavado broncoalveolar, fluido pleural, fluido pericárdico y fluido ascítico, provenientes de pacientes con leucemia aguda y crónica, síndromes mielodisplásicos, linfomas, mieloma, enfermedades autoinmunes, inmunodeficiencias y tumores sólidos, entre otras enfermedades. La citometría de flujo proporcionó información importante sobre la clasificación y detección de números mínimos de células tumorales en casos de leucemia y linfoma. Este trabajo representa el primer reporte nacional que describe la implementación de citometría de flujo en muestras especiales para diagnóstico y monitoreo clínico de pacientes con patologías malignas y benignas.

Palabras clave: fluidos corporales; citometría de flujo; inmunofenotipo.

Estudo de amostras de fluídos corporais utilizando citometria de fluxo: seis anos de experiência no Hospital Universitário San Ignacio - Pontificia Universidad Javeriana, Bogotá, Colômbia

Resumo. A citometria de fluxo foi implementada em 2008 na Pontificia Universidad Javeriana e posteriormente no Hospital San Ignacio com a finalidade de examinar amostras especiais de pacientes com malignidades hematológicas e tumores sólidos diferentes aos de medula óssea e sangue periférico para diagnóstico e monitoramento. Este estudo descreve as principais descobertas a partir da avaliação de amostras especiais em um período de 6 anos. Se examinaram por citometria de fluxo um total de 1.070 amostras de fluídos corporais de pacientes doenças malignas e benignas. Estas amostras se estabilizaram com TransFix ${ }^{\mathrm{TM}}$ e coradas com painéis imunofenotípicos de seis cores. As amostras incluíram fluído cérebro-espinhal, lavado broncoalveolar, fluído pleural, fluído pericárdico e fluído ascético, provenientes de pacientes com leucemias aguda e crônica, síndromes mielodisplásicos, linfomas, mielomas, doenças autoimunes, imunodeficiência, e tumores sólidos, entre outras doenças. A citometria de fluxo proporcionou informações importantes sobre a classificação e detecção de um número mínimo de células tumorais nos casos de leucemia e linfomas. Este trabalho representa o primeiro relato nacional que descreve a implementação de citometria de fluxo em amostras especiais para diagnóstico e monitoramento clínico de pacientes com patologias malignas e benignas.

Palavras-chave: fluídos corporais; citometria de fluxo; imunofenotipo. 